\title{
From 'Politics in Command' to 'Economics in Command': A Discourse Analysis of China's Transformation
}

\author{
LI XING
}

\begin{abstract}
This article proposes a framework for understanding the way the Chinese Revolution emerged, developed and achieved power (1921-49), then further consolidated in the period of socialist 'uninterrupted revolution' (1949-77) and was finally abandoned by the post-Mao regime (1977 to the present). This analysis is based on a perspective of discourse theories framed in historically new forms of political, social and ideological relations. In other words, it attempts to conceptualize the transformation of China and the Chinese Communist Party by analysing the role of ideological discourses (arguments and interpretations) and the cognitive elements (beliefs, goals, desires, expertise, knowledge) as the driving-force behind societal transformations. The discourse theory applied here - logocentrism and econocentrism - also serves both as a political arena of struggle to confer legitimacy on a specific socio-political project and as a distinctive cognitive and evaluative framework for understanding societal transformations. The conceptualization of the paper is informed by the work of David Apter and Tony Saich on discourse theory.
\end{abstract}

\section{Introduction}

China's attempt to safeguard its existence as a prosperous, strong nation and a united political entity has been the driving force in recent times. The earlier 'attempts' at modernization suffered a series of setbacks emanating from both internal and external forces. ${ }^{1}$ In an attempt to transform and reinvigorate their nations, first Russia and then China eventually found some answers in Marxist teachings and revolutionary theories. Depending on how one assesses the successes and failures of the Chinese Revolution and Maoist socialism, China will be remembered for its historically unique experiment to skip over the stage of capitalism as laid down within Marxist orthodoxy and to bring about a socialist 'great leap forward' not only in its political, economic and social structures but also in the cultural traditions and consciousness of its people. It achieved this in ways that defied conventional ideological and political norms in both 
established capitalist as well as socialist states. With the introduction of 'market socialism', China is undertaking a modernization process by embracing capitalist practices, while at the same time integrating itself into the existing capitalist world system.

In the last 50 years of its existence, the People's Republic has witnessed two major social projects which have transformed the nation:

Firstly, a Maoist China that took a socialist development strategy characterized by:

- co-operative and state (public) ownership and control of the means of production and distribution;

- a highly centralized system of planned economy; mass campaigns for the elimination of economic and political inequalities as well as class privileges, which were believed to retard economic development and prevent the full utilization of human resources and potential; and

- the dominance of the group interests of the immediate producers at the workplace and of working people in all spheres of society, including resource allocation and control over politics and ideas.

Secondly, a Dengist China that is taking the capitalist road of economic development based on:

- privatization of ownership and control of the means of production and distribution;

- marketization of the economy; enlarging socioeconomic inequities and political privileges;

- emphasizing science and technology as the essential productive forces; and giving priority to the interests of the privileged, professional and entrepreneur classes.

How can we reconcile this dramatic social and ideological discontinuity that characterizes China between the two periods? How can we explain and interpret this historical transformation, within the framework of fundamental changes in ideas, beliefs, value systems, and the ways of thinking of Chinese people?

\section{Objective and Methodological Consideration}

This article proposes a framework for understanding the way the Chinese Revolution emerged, developed and attained power (1921-49), then further consolidated in the socialist continuation period (1949-77) and was finally abandoned by the post-Mao regime (1977 to the present)(see Figure 1). The analysis is based on a perspective of discourse theories 

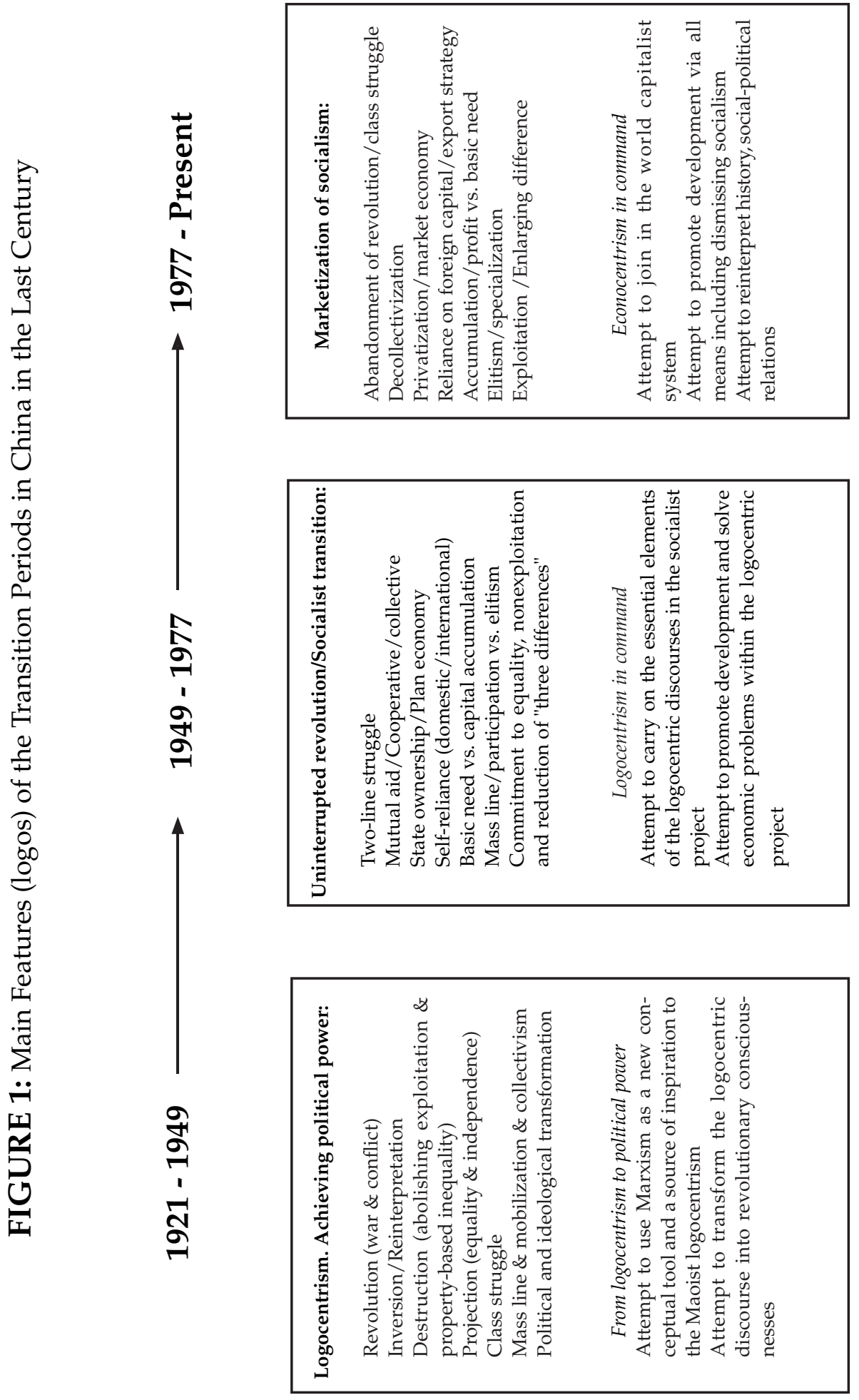
framed in historically new forms of political, social and ideological relations. In other words, it is an attempt to conceptualize the transformation of China including the Chinese Communist Party (CCP) by analysing the role of ideological discourses (arguments and interpretations) and the cognitive elements (beliefs, goals, desires, awareness, knowledge) as the driving-force behind societal transformations.

Discourse analysis, as used within the context of this paper, is an approach to study the interrelationships between cognition/consciousness (language, concept, notion and comprehension) and society (politics, economics and policies). Since meaning is discourse-dependent, discourse analysis sees the construction of language (argument, expression and explanation) as imbued with powerful meanings and significance in socio-political contexts. In other words, the foreground of discourse analysis implies that language use (terminology, vocabulary and expression) in social and political context entails essentially a matter of 'actions', i.e. enacting activities, perspectives and identities, rather than just 'constitution' of arguments. After all, discourses are social languages (Gee 1999) because they are tied to social relations, identities, power, inequality, class struggle, etc.

The advantage of such an approach lies in its theoretical, methodological and analytical usefulness in understanding the effect of discourses on the macro-context of historical, social and political practices. Discourse analysis here refers to:

modes of argument that are more consistently generalized and speculative than normal scientific discussion.... Discourse, by contrast, is ratiocinative. It focuses on the process of reasoning rather than the results of immediate experience, and it becomes significant where there is no plain and evident truth. Discourse seeks persuasion through argument rather than prediction. Its persuasiveness is based on such qualities as logical coherence, expansiveness of scope, interpretive insight, value relevance, rhetorical force, beauty, and texture of argument. (Alexander 1988: 80)

Discourse is often expressed in the form of theories, and discourse theories are constructed to offer a particular type of explanation to legitimize certain political and ideological ideas. Discourse theories are often established at both epistemological and ontological levels, aiming to defend particular orders of justification in the course of deliberating over the appropriateness of a socio-economic system. To be more specific, discourse analysis is related to the study of important concepts such as identity, conflict, power, dominance and inequality, and the role of the state or state institutions. It denotes a process of societal, cultural and 
ideological reconstruction or reproduction through 'language used in tandem with actions, interactions, non-linguistic symbol systems, objects, tools, technologies, and distinctive ways of thinking, valuing, feeling, and believing' (Gee 1999: 11).

Discourse analysis does not attempt to provide a tangible answer or solution on the basis of scientific research. It promotes the understanding of the conditions behind a specific 'problem' (conflict, war, contradiction, environment, etc.) and interprets the essence of that 'problem' and its resolution. It is expected that the promotion of understanding can lead to changes in the practices of an institution or a society as a whole. Discourse analysis cannot be categorized either as a qualitative or quantitative research method. Rather, it aims to question the basic assumptions of the established research methods. When applied, the reliability and validity of one's research depend substantially on the force, logic and quality of one's analysis and rhetoric. However, it is also subject to counter-interpretation and counter-argument.

\section{Discourse Theories: Econocentrism and Logocentrism}

The idea adopted in this article of applying discourse theories and the two central models (econocentrism and logocentrism) together with a few other concepts, is inspired by David Apter and Tony Saich's book, Revolutionary Discourse in Mao's Republic (1994). This book provides a new way of understanding the power of political ideas and their impact on the mobilization of political movements. It constructs a unique approach to the role of political discourse as powerful symbolic capital in interpreting the revolutionary process in Mao's China.

The present article not only seek to apply Apter and Saich's framework of discourse theory and use the two competitive models as analytical categories, but also to contexualize/exemplify them in combination with my own research on China's development. In other words, this article aims at shredding light on how their discourse approach relates in specific ways to the understanding of China's major transformations in the last century. Such an endeavour is based on a number of propositions:

1. The historical transformation of China in its various social, economic and political guises takes place against a background of specific discourses;

2. Political discourses have played a vital role in the Chinese construction of social, political and cultural meanings and identities for a specific hegemonic project; 
3. The latest transition of China from socialism to capitalism (market socialism) can be conceptualized as demonstrating how the previous hegemonic discourses become dislocated when new events cannot be integrated, represented or domesticated;

4. The relationship between the two paradigms (logocentrism and econocentrism) is a recurrent dialectical process of mutual generation and mutual destruction.

\section{Econocentrism}

In its specific form, econocentrism refers to a belief that the economic mode of production absolutely determines a society's social, political and intellectual life. It accepts the primacy of economics as a point of departure in the production and reproduction of social life due to human 'rationality'. In other words, it is an ideology that views economics as the key determinant in the course of human history.

Today, the econocentric worldview dominates every sphere of our everyday lives. All theories of rational choice and major theories in politics, sociology, international political economy, international relations, and development studies are constructed on the premises of economic analysis or within the framework of economic thinking as their primary paradigm of interpretation. Most concepts, which are operated daily, such as 'culture', 'ideology', 'nationalism', 'democracy' etc., serve either as residuals or supplements to econocentric models. It is generally accepted that economic structure in one way or another determines aspects of human activities and social relations, and economic dominance leads to political and ideological leadership.

At the core of the econocentric model is methodological individualism, in which politics is perceived as a process that 'objectifies private and individual wants and desires in the form of social needs and priorities according to distributive schedules and alternative possibilities'; while power is associated with rationality - bargaining and compromising forms of politics in which interests often prevail over principles and negotiations over confrontations (Apter and Saich 1994: 3-4).

If one applies the above to the present era of Chinese econocentrism, it is not difficult to see that the notion of 'socialism' has been reinterpreted by the incorporation of the market as an inseparable element of the socialist economy. Socialism, according to the reformist understanding, 'can only appeal to the people with the basic goal of enriching the country and its people, not yet the higher goals of social equality and the full development of the person' (Ogden 1996: 656). The meaning of socialist 
development has been redefined in the language of an uncompromising economist and its goal is 'to achieve a "pragmatic" adjustment of revolution to the demands of present reality' (Dirlik 1989: 32).

\section{Logocentrism}

The word logo originates from the Greek, meaning 'word' or 'speech'. In its general form, logo is short for logogram and logotype, which refers to 'a name, symbol, or trademark designed for easy and definite recognition'.2

Logocentrism, philosophically, is a concept used in critical theory to designate how thought systems are organized around fundamental assumptions about reality and truth. It was a key concept in the thinking of Jacques Derrida and of deconstruction theory. ${ }^{3}$ Logocentrism argues that language, in terms of explanations and interpretations, is composed of elements of linguistic signs, which are accorded with meaning and significations (logos and symbols). Since language and texts are always tied to experience, the use of language contains perception, conceptualization, power and position.

Politically, logocentrism aims to display an alternative worldview and a new interpretation of truth and reality. It is explicit in its objective to reconstruct the world through strategies of cognitive awareness and critical thinking at both ontological and epistemological levels leading to political mobilization and struggle. These strategies contain a process of searching for alternative perspectives, for what can be brought to light, for what can be signified, and for the narrative structure of new explanations. Narratives can become the new totalizing logos, which, in return, gather multiple narratives for practical purposes. It is perhaps precisely according to the above interpretation that Mao, in a similar way to Gramsci, assigned a more pivotal importance to conscious activity than did Marx (Dirlik 2003).

Hence, political power can be generated through logo (language and symbol), i.e. through both power behind discourse and power in discourse. The logocentric mode of power 'is concerned less with choices than with projections made on the basis of some doctrinal definition of necessity that specifies its own rules and theoretical principles and for which it provides its own logic' (Apter and Saich 1994: 4, emphasis added). Its central goal is to re-establish social order based on a redefined and projected justice and equity. It looks into the conscious part of human life and emphasizes learning and education as the key to power, and knowledge and wisdom as a form of truth. Logocentric power is 
identified as possessing proto-religious characteristics intertwined in a secular theory of politics (ibid.: 3)

The logocentric power based on political discourse and symbolic capital is able to unleash potential energy to create a political community under conditions of virtual chaos and disintegration. The construction of alternative discourses can transcend randomness and create a logic of order so that the condition of disorder itself becomes the condition of transition and even transformation. Logocentrism cultivates a common interpretation of shared history and experiences. To join in a revolutionary movement implies 'to think one's way past current predicaments and arrive at fresh, new solutions at once comprehensive and radical, most importantly, in concert with others'. Such a movement must be 'one that has at its disposal its own language, discourse, myths and logic' (ibid.: 8, emphasis added). Armed with the deployment of its own categories, logocentrism attempts to resolve the contradictions of historical legacy in its own favour in order to pave the way for great economic, social and cultural transformations.

\section{Logocentrism and the Chinese Revolution ${ }^{4}$}

The dynamic strength of logocentrism in the context of the Chinese revolution lies in its effort to generate power through an inversive discourse, i.e. inversing the econocentric paradigm and social order, based on its own language of conviction together with ideological, ethnic, linguistic strands. The historical role of the Chinese logocentrism can be analysed via four propositions, as set out below.

1. To change people's worldview through a reinterpretation of history and narrative reconstruction of reality in order to think one's way out of current predicaments.

Logocentric Maoism (as mentioned, a form of sinified Marxism emphasizing the role of conscious awareness) related China's underdevelopment to the outcome of a historical process caused by the Western colonial-imperialist expansion rather than to the 'stage of development' defined by the modernization school or to the consequences of a specific mode of production in connection with cultural barriers. ${ }^{5}$ From this perspective, underdevelopment was not an inborn characteristic of preindustrial societies but a consequence of a specific historical process.

After numerous failures of resistance to Western imperialist challenges since the Sino-British Opium War in the 1840s, Confucianism as a state ideology and as an enduring vehicle for ethical and political traditions, 
finally lost its viability at a time when China urgently needed a new analytical framework to understand its fall. Some analytical categories and aspects of Marxism, and especially Lenin's theory of capitalist imperialism, provided Chinese intellectuals with a partial theoretical framework as well as a psychological answer to help explain the failures of traditional Chinese culture and the humiliation suffered at the hands of the West (Peck 1975: 73).

Thus, when Confucianism failed to function satisfactorily as a state ideology, many Chinese revolutionary intellectuals turned to Marxism-Leninism as a way of reconceptualizing the world from different ontological perspectives embedded with concepts that were alien to the Chinese society of the time. China, as they saw it, was no longer an isolated centre of the globe surrounded by barbarians, but a constituent part of the world replete with different forces and ideas. They reconceptualized China's role in international affairs from being at the center of the world and a universal authority to recognizing China's problems as sharing in the world's problems. ${ }^{6}$ From this perspective, the struggle of Chinese people, and the radical revolutions that were taking place all over the country, could not be detached from the outside world. The attraction of Marxism-Leninism for the Chinese was that, as Kapur observed:

(a) [...] It was an effective ploy to criticize the West from a Western point of view; (b) it gave the Chinese a new methodological framework to understand their own past and foresee the contours of their future; (c) it offered a conceptualized view of international reality. Lastly, it amply proved its anti-imperialist credentials - an important source of attraction - after the 1917 Bolshevik Revolution when the Soviet leaders denounced imperialism, unilaterally abolishing unequal treaties and relinquishing many privileges of tsarist Russia including extraterritoriality as well as their share of Boxer indemnities. (Kapur 1987: 3)

\section{To unite people based on collective individualism and a social,} political and economic divide.

Logocentric Maoism persuaded people to link their private narratives and personal interpretations to that of the collectivity. It called for individual contribution but with collective outcomes. Such a strategy aimed to analyse Chinese society through the lens of a sociocultural and economic divide (class division), and to relate this divide to the superstructure of society. In a society where people are divided into different classes, all men possess certain class interests and relations. All realms of human relations, such as values, rights, dignity, liberty, 
freedom, love and hatred, humanity and inhumanity, etc., can only be understood and explained through concrete historical and class analysis (Chen 1984: 41-44). Logocentric Maoism persuaded people to think that all political conflicts could be comprehended in terms of the divide. The purpose of generating societal transformation is reached when the majority of members of all social strata interpret politics and participate in the struggle in terms of this divide.

Both the failure of Sun Yat-sen's Republic Revolution (which was inspired by Western constitutional monarchy and republicanism) and the rise of Japan, assisted by its militarist culture, led China's early revolutionary pioneers to conclude that neither the West nor Japan could be emulated as alternatives to save and develop China. The question then arose: what other development options might suit the particular conditions and needs of the Chinese nation? Early Marxists like Li Dazhao and Chen Duxiu argued that with or without a strong state, the establishment of Chinese capitalism would eventually become the agent of Western capitalism and that this would fail to solve the problems of poverty and backwardness in China. The most forceful and comprehensive arguments were put forward by Li Dazhao:

[A]lthough China itself has not yet undergone a process of capitalist economic development such as occurred in Europe, America, and Japan, the common people [of China] still indirectly suffer from capitalist economic oppression in a way that is even more bitter than the direct capitalist oppression suffered by the working class of the various (capitalist) nations[...]

If we look again at the international position of China today, [we see] that other nations have already passed from free competition to the necessary socialist-cooperative position, while we are still juveniles; others have walked a thousand $l i$, while we are still taking the first step[...] I fear that we will be unable to succeed unless we take double steps and unite into a socially cooperative organization. Therefore, if we want to develop industry in China, we must organize a government made up purely of producers in order to eliminate the exploiting classes within the country, to resist world capitalism, and to follow [the path of] industrialization organized upon a socialist basis. (Li in Kung, 1975: 259)

Li's argument identified China as a 'proletarian nation', although it lacked a strong industrial working class. He likened the potential of a Chinese proletarian revolution to the worldwide movements against international capitalism and imperialism. His far-reaching and insightful analytical worldview paved the way for the establishment of a populist tradition within the Chinese Communist Party, which was further developed by his disciple, Mao Zedong. 
Armed by an inversive discourse based on the conceptual power of class divisions, the CCP aimed at transforming the Chinese people from being like 'a sheet of blank paper'7 to becoming ideologically and politically conscious. By becoming members of this inversive revolution, the Chinese would begin to see themselves as decision-makers, as agents of social transformation, as masters of their own destiny, rather than as passive victims, bending to the will of their political masters.

\section{To project a future based on structural transformation rather than evolutionary modifications.}

The immediate context of Maoist logocentrism was conflict and chaos, war and revolution - not reformism or evolutionism. Logocentrism rejected the current reality or truth, in favour of a projected structural transformation yet to be realized. It attempted to constitute a new hegemonic project - a moral economy, not a political economy - that was inversive in object and transformational in consequence.

Some scholars argue that even though imperialist penetration did bring elements of modernity to China, the impact was geographically confined and sectorally skewed to serve foreign interest (Esherick in White 1982: 114). The reason why China was able to industrialize more rapidly after 1949 was that the 'Communist revolution decisively broke the ties that chained China to the imperialist system' (Mould in White 1982: 114). In other words, China went straight to the roots of its historical problems and made radical structural transformations - unique experiments to skip over the stage of capitalism and to bring about a socialist transformation in terms of both society and the consciousness of its people.

\section{To continue the logocentric tradition and bring 'uninterrupted revolution' into the socialist project.}

After the communist victory of 1949 and with the successful development of the socialist economy and transformation in the early 1950s, few people in the communist leadership thought of a continuous revolution in terms of a prolonged period of struggle. Revolution was mainly regarded as the act of seizing power, whereas the building of a new economy and social order would require a different methodology. Nevertheless the next three decades witnessed the continuation of the Chinese revolution through a progression of several mass movements, such as the Great Leap Forward in the 1950s, the Anti-rightist Movement and the Great Proletarian Cultural Revolution in the 1960s. Mao's theory of uninterrupted revolution was practised during these experiences based on the conviction that even under socialist development, the revolution 
must continue. Among those experiments, the Cultural Revolution was perhaps the most dramatic example of a nation in search of a strategy that would avoid a return to the 'old' paradigm to resolve socialist contradictions and to continue an independent self-reliance path ( $\mathrm{Li} 2001)$.

The meaning of 'uninterrupted revolution' should be understood as referring to the preservation of some important logocentric continuities in Mao's thoughts and practices, as Selden summarizes:

They include the fierce commitment to eliminate exploitation and propertybased inequality; the emphasis on political mobilization, class struggle, and political and ideological transformation and their relationship to economic development; the proclivity to replace the market and the household economy by large cooperative, collective, and state institution; and the emphasis on self-reliance and the suspicion of intellectuals and technical personnel. (Selden 1989: 54-55)

In Mao's view, the theoretical and ideological basis for continuous revolution during a peaceful development period was very important. He believed that an uninterrupted revolution was an objective necessity reflecting both the material conditions of China and the Chinese people's desire and aspiration for social change. He explained that:

China's 600 million people have two peculiarities: They are first of all poor, and secondly, blank. This may seem like a bad thing, but it is really a good thing. Poor people want change, want to do things, want revolution. A clear sheet of paper has no blotches and so the newest and most beautiful words can be written on it. (Mao in Kung 1975: 292)

Poverty and blankness was seen by Mao as political capital - a driving force not only for revolution to transform China but also for economic development to build a strong and prosperous socialist state. This view was built on his observation and conceptualization of human beings as the most valuable social capital: 'of all the things in the world, people are the most precious. As long as there are people, every kind of miracle can be performed under the leadership of the Communist Party' (Mao in Eckstein 1977: 33). The political and ideological nexus is clearly recognized:

In man, the producer, motivation derives from consciousness, which in turn comes from social practice. Motivation is the source of moral energies, such as dedication, devotion, determination, faith, frugality, industry, and simplicity. Consciousness and motivation reinforce each other, and can be transformed into material force through man's labour. (Kung 1975: 292-93)

This is a completely different world outlook from that of market economic theories, which highlight the market mechanism and individual profit-seeking as an invisible hand directing economic development. 
That Mao seemingly politicized the question of socialist construction was due not to his intention to challenge the economic rationality, but to his attempt to use politics to mobilize human resources and all social forces in the service of economic development. In other words, it was an endeavour to transform symbolic capital into economic capital.

In order to fully utilize human beings as an effective instrument in the socialist project, Mao sought to establish a worldview in which the part is seen in relation to the whole. Specifically, this worldview aimed at broadening the concept of the 'whole' - which had been narrowed to imply loyalty to one's family, village and clan - to the consciousness of the class, the nation and beyond. The goal was to form in society a Gong-outlook in contrast to the Si-oriented one. These two Chinese words have strong logo connotations, with the former expressing collectivity, solidarity and public orientation, and the latter referring to selfishness, individualism and ego-outlook. The socialist wage policy, which attempted to bridge income differences at that time, reflected such incentives. In the industrial sector, wage differentials were either stabilized or reduced, whereas in the people's communes, income through alloting working points was based not only on the individual's material contribution to total production, but also on the level of his/her political consciousness and socialist devotion.

\section{Econocentrism and 'Market Socialism'}

The period from the 1980s to the present is the great age of econocentrism and pragmatism in the history of China. It also marks a significant paradigm shift in which the econocentric discourse has become the engine to transform the state and society. The 15th Communist Party Congress enshrined Deng Xiaoping Theory in the Chinese Communist Party Constitution alongside Mao Zedong Thought. The core ideological discourses underlining the Dengist reform practices can be summarized as follows:

- China's industrialization program should proceed beyond the assumption of a socialism-capitalism dichotomy as illustrated by Deng's 'Cat Theory'. That is to say, in relation to its modernization project, China must be open to all theories and practices regardless of their socialist or capitalist nature or origin.

- Practice (pragmatism and wealth) is the sole criterion of measuring the truth of any theory or thought. In other words, any idea and strategy that can bring about a satisfactory result of capital accumulation will be considered useful and reliable. By this token, socialism 
must be flexible in the practical context of the world system. In this sense, pragmatism will lead to truth and power.

- The modernization process should take into consideration China's particular situation and needs, i.e. 'building socialism with Chinese characteristics'. This rejects the idea that Chinese socialism has been theoretically completed and practically established; and China's present socialism will continue to be open to all sorts of experiments in the manner of 'crossing the river by touching the stone'. 8

- Instead of viewing people as the essential element of production, Dengist thought shares with market economism the conviction that science and technology are the prime productive forces; and it sees the market as being a catalytic force and as ideologically neutral.

However, while the fundamental principle of the entire reform process is no doubt econocentric, the reform theorists and designers also understand the discourse power attached to logocentrism. In an effort to promote capitalism without cognitive disconnection from socialism, they have struggled to construct an awkward mix combining socialist logo (the socialist identity) on the one hand and capitalist market forces on the other. Such a mixture is clearly reflected in the many new terms invented for theoretical finesse and ideological justification, such as 'socialist market economy' or 'market economy with Chinese characteristics', and 'Confucian businessman', which are politically and economically self-contradictory.

However, behind the 'Chinese characteristics', we are presented with the logocentric ingredients of 'adherence to the primacy of socialism', 'supremacy of the leadership of the Communist Party', 'adaptation of Marxist principles to the conditions of China', etc. The purpose of sticking to these logocentric tenets is to generate a similar transformative effect but no longer for revolution and socialism. Rather, they are intended to rationalize and legitimize the econocentric reform practices. The legitimizing process consists of a series of theoretical articulations geared towards a new interpretation of the truth and reality as follows:

\section{The 'Cat Theory'}

The key logic of Deng's 'Cat Theory' ('it doesn't matter whether the cat is white or black as long as it can catch the mouse') is that if capitalism can produce positive results, then it is good for socialism too. It is an expression of metaphysical and mechanical materialism that is based on highly pragmatic and practical assumptions. It seeks to reinterpret the relationship between productive forces and production relations 
so as to establish that the basic determinant of human history is not politics or class struggle, but economics, especially the development of the productive forces of society.

According to this theory, the criteria for judging socialism and capitalism should be whether it is beneficial to productivity development, enhancing the overall national economic strength, and improving the people's living standards. If anything is beneficial in these senses, then it can be considered socialist. Its flaw lies in the fact that it rates productive forces much more highly than production relations. Seen from the basic principles of socialist production relations, and taking account of China's market reform in the past two decades, this ideological paradigm represents a historical 'great leap backwards' since the new socio-economic system is established by developing the productive forces but at the cost of dismantling the socialist production relations.

\section{'Socialist Primary Stage' ${ }^{\prime 9}$ and 'Science and Technology as the Prime Productive Forces'}

Closely related to the Cat Theory, another theoretical argument in support of the reform program seeks to redefine the conceptual understanding of 'Chinese socialism'. One of China's key reformist intellectuals, Su Shaozhi, claimed that China 'is still in a transition period from pre-socialist to socialist society, still catching up with the missed lessons of capitalism' (Su 1983: 175). Accordingly, it is now argued that given the level of the productive forces in post-revolution China, the failure of socialism is due to the rapidity of the transition to 'full' socialist relations of production. This 'Marxist' interpretation of China's development lays the foundation for the theoretical justification of reform policies: namely, that China could not take the socialist road without going through the stage of fully developed capitalism (Su 1990).

The reformist elites argue that according to Marx, socialism and communism must originate from mature capitalism, but unfortunately Chinese socialism did not emerge from the womb of highly developed capitalist society but from a semi-colonial and semi-feudal society. Even though during the socialist transition period, China had undergone lengthy and profound transformations in the realm of social relations and relations of production, yet this still could not free it from the relics of the old society. Based on this type of interpretation, it is maintained that 'history has decided that many conditions that in a general historic view must be prepared in the capitalist stage must continue to be fully prepared by us in the course of building socialism' (Lu 1983: 22). 
Historically, however, social transformation is not necessarily determined by the level of economic development, but by the seizure of political power by a class or classes committed to and capable of generating structural changes: the Industrial Revolution in the West and the first socialist revolution in Russia and China were achieved following the seizure of political power by a committed class (Selden 1979: 21). In this sense, the success of revolution and transformation depends first and foremost on achieving political power. Politics is the social engineering of coercion, rationalization, legitimization and imposition involving enforced variation, reshaping, selection and distortion.

Therefore, the emphasis on the promotion of the productive forces needs critical rethinking. On the one hand, the establishment of new socialist production relations, based on the econocentric view, does not necessarily bring about the advance of productive forces because the material-centred profit incentive cannot be avoided in stimulating economic activities. Accordingly, if the development of the productive forces is set as a precondition, then the market mechanisms will have to be incorporated. On the other hand, the situation in China today reconfirms the logocentric interpretation of the truth and reality: the introduction of market functions eventually leads to inequalities and polarization, which endangers the establishment of socialist production relations. The present situation of polarization between the working class and the propertied class is more akin to the 'primitive stage of capitalism' than to any stage of socialism.

\section{'Middle-Class Stability' ('Let Some Become Rich First')}

'Class' has been a political concept and a socio-economic category since the time of Marxism's introduction into China's modern revolutionary history. It played a vital role in the post-revolutionary period. ${ }^{10}$ Before the economic reform, 'class' was generally defined in terms of political, family and occupational criteria that were used to mobilize mass participation both for political movement and for economic development.

Since the 1980s the CCP declared the end of class struggle and has since gradually banished class discourse from the official ideology in dealing with domestic and international affairs. This de-class proposition is claimed to be based on the present reality that 'The system of exploitation of man by man has been eliminated, and exploiters no longer exist as classes' and 'with the abolition of the exploiting system and the disappearance of the exploiting classes, they [exploiting classes] have lost the political and economic basis to exert power; they are scattered, 
unstable and their numbers and scope of activity are greatly limited' (Beijing Review 44, 1981). However, ironically, it is actually during this reform period that we are seeing the emergence of a real class society.

In order to unleash the productive forces, it is necessary for the reformists to transfer certain power from the political bureaucracy to those with technical and professional expertise (from 'red' to 'expertise'). ${ }^{11}$ Behind this power transfer there lies the political discourse in which science and technology are elevated to become the prime productive forces; and where the objective of market socialism is to create a new technocratic-managerial class as the leading productive force for modernization. This new class consists of the same people who were the 'red bourgeoisie' (in terms of nepotism and privileges, not necessarily in terms of wealth and production relations) during the Cultural Revolution. Today they are becoming the real bourgeoisie as a result of the current marketization process and through the new production relations that make privatization possible.

The reformist intellectuals who favour the development of capitalism base their arguments on the theory of 'middle-class stability'. Taking the advanced Western capitalist societies as its point of departure, this theory claims that these societies are much more homogeneous 'because of the presence of a large middle class ( 40 percent of the total population) which acts as a social stabilizer, and the richest and poorest constitute only a very small proportion of the overall population'; and 'when most people's living conditions are considered to be at a middle level, the social structure is stable' (Li 1997: 48). Thus, it is assumed that a phase of capitalist development is necessary to accelerate the construction of the material base essential for developing socialism in the future, and to reinforce state power and raise the living standards of its people. Such an assumption is built on the belief that despite the capitalist mode of functioning, the objectives of socialism, nationalism and common wellbeing will be served eventually.

Paradoxically, the new Chinese wealthy class is largely generated from within the ranks of the Communist Party. It is politically dependent on the Party and economically tied to the 'de-socialist' free market. The current situation in China is running counter to the theories of the reformists. Ironically, many of today's contradictions in China's market socialism are those of class struggle. Class divisions and struggles at local, regional as well as national level will become the key socio-political problems affecting China's industrialization in the near and medium term. This is due to the refusal to dialectically understand the true tenet 
that the means and ends of capitalism are not easily separated. Indeed, the more economically successful methods of capitalism are utilized, the less socialist ends will be possible (Meisner 1997: 269; Weil 1996).

\section{'Three Represents'}

The 'Three Represents' is part of the ideological reconstruction of the $\mathrm{CCP}$ in the current critical period of dramatic societal transformations. Again, it is part of the CCP's ongoing attempt to legitimize China's econocentric 'market socialism' through injecting logocentric capital for the purpose of ideological and theoretical justification.

It was said that the 'Three Represents' was first formulated by the former President Jiang Zemin. It refers to the three areas which the CCP represents: (i) the requirement to develop advanced productive forces, (ii) an orientation towards advanced culture, and (iii) the fundamental interests of the overwhelming majority of the people in China. Although it is an awkwardly named theory approved by the Communist Party Congress, it reflects the fact that there is a continuous need for theoretical and ideological justifications at the state and party levels to take account of the political, economic and social transformations brought about by the rapid economic development. 'Advanced productive forces' (the new business elite), 'advanced culture' (Confucian culture of social harmony and respect of authority and social order) and 'fundamental interests' (the new social constituencies) are strong discourses (logos) aiming to legitimize the consequences generated by the econocentric reform policies and to reinterpret a number of transformed relations (party, state, private economy, class, civil society, cultural changes, etc.).

Among the transformations, the change in class relations, such as the increased role of private entrepreneurs in China's economy in creating new jobs and wealth, is perhaps one of the most important factors behind the 'Three Represents'. The Chinese Constitution theoretically defines the working class as the key socio-political component in control of society and the work unit. However, industrial labour today has in reality been turned by the economic marketization into a commodity 'owned', or at least controlled, by party elites, private business groups and multinational corporations. The state is increasingly willing to sacrifice labour welfare and social stability in exchange for a rapid increase in productivity (Li 1999).

The marketization of the economy has brought about the transformation of social/class relations in a number of areas. First, it makes economic calculations the priority of Guanxi, promoting economic 
antagonism and precluding solidarity. ${ }^{12}$ Second, it absorbs people's devotion, energy, capacity and resources, and confines them within a narrow framework of economism. Third, it hides production/class relations and separates them from the market relations so that the exploitation or unequal social/class relations in production are ignored while the equal relationship in market competitions is emphasized.

Today with the increase in the privatization process, the economic power of China's new bourgeoisie (middle class) is also growing. ${ }^{13}$ The situation is very ironic: the new capitalists today are much stronger and wealthier than they were before the socialist transformation in 1953. To protect their interests, they have raised the demand for political recognition and governing power. Besides creating their own types of associations, a large number of private capitalists have already entered the People's Congresses and People's Political Consultative Conferences at different levels (Chen 1999), which will sooner or later transform the existing political system and power structure.

\section{Concluding Remarks: the Dialectics between Logocentrism and Econocentrism}

This article has attempted to explain the contemporary transformations taking place in China by focusing on the importance of discourse theory - logocentrism and econocentrism - as (i) a political arena of struggle for conferring legitimacy on a specific sociopolitical project, and (ii) a distinctive cognitive and evaluative framework for understanding societal transformations. This type of approach rests on the particular criteria of explanations and interpretations inscribed within the cognitive grammars (such as socialism, class, Confucianism). For example, the reformist discourse grammar is embedded with strong political grammars thereby serving a theoretical and ideological function of policy rationalization and legitimization. From this standpoint, certain systems (marketization, privatization) and practices (de-welfare, commodification of health care, etc.) are vindicated as rational and historic while other practices are discredited as irrational or ahistoric. The post-Mao transformation explains that political discourses are not only a way of expressing viewpoints but also a weapon to legitimize necessary changes.

The failure of the Maoist logocentric socialist project is an interesting topic for research if one adopts the perspective of Gramscian political theory of hegemony ( $\mathrm{Li} \mathrm{1998).} \mathrm{Socialist} \mathrm{hegemony} \mathrm{must} \mathrm{incorporate}$ and adjust to the pre-revolutionary material, social, political and cultural heritage. The logocentric discourses represent a powerful method 
of analysing and exposing the defects of capitalist society (econocentrism). However, it is highly questionable whether solutions to these problems and the post-revolutionary contradictions in the domains of social relations, such as party/state/civil society, class/ideology, and culture/revolution, etc., can be properly accommodated within the logocentric framework.

Logocentrism is able to reinterpret reality and truth because when it takes the form of symbolic capital (logo), it is capable of turning reality upside-down. But the question is: how long can symbolic capital last without the injection of adequate economic capital? Did Mao's dilemma lie between the political necessities of 'uninterrupted revolution' on the one hand and economic rationality of capital accumulation on the other? When symbolic capital (logocentrism) is applied to enlarge economic capital (the Cultural Revolution, mass-line approach to industrialization), its principles (discourses) have to face some systematic realignments between needs, desires, preferences, and interests other than symbolic and moral elements. This can also be explained by Gramsci's (1971) two aspects of an individual's common sense (worldview), which consists of a variety of elements, some of which may contradict the dominant ideology.

Although the Dengist market reform is no doubt based on econocentrism, it has also shrewdly 'borrowed' the strength of logocentric capital in order to legitimize reform policies theoretically. However, if logocentrism is believed to be vulnerable to the advances of econocentrism, so too is the latter vulnerable to the resurgence of capitalist diseases, namely social inequality, moral decay, class polarization, unemployment, etc. The dilemma for econocentrism is that it tends to generate societal contradictions for the revival of a logocentric movement. The 'Min Zhu Qiang' (Democracy Wall) movement at the end of the 1970s ${ }^{14}$ - and especially the student demonstrations in 1989, together with the support it received from citizens who protested against the new social inequities and official corruption - testified to a great deal of spirit and courage inherited from the Cultural Revolution ( $\mathrm{Li} 2001$ ). The persistent popularity of Mao, almost three decades after his death, is not just a matter of historical nostalgia but a durable symbol of justice and equality. ${ }^{15}$

It is believed that China's future development, whether political, economic or cultural, will inevitably in one way or another link back to some facets of Mao's historical legacy and his logocentrism. The prospects for Chinese socialism, if we believe there will be any, will surely not evolve from the existing socio-political establishment. Rather, it 
will probably emerge from strong popular responses and resistances among the 'new' classes of exploited populations to the deterioration of political and social welfare conditions, and from a series of struggles against the distortions and consequences generated by China's protocapitalist practices.

Li Xing is Assistant Professor, Research Center on Development and International Relations, Aalborg University, Denmark.

\section{NOTES}

1 They include yang wu yun dong (modernization movement) after the Sino-British Opium War (1840-1842), wu xu bian fa (the imperial institutional reform movement of 1898), and the 1911 Revolution under Sun Yat-sen.

2 Source: The American Heritage® Dictionary of the English Language. Fourth Edition.

3 See Derrida $(1973,1976,1978)$.

4 The Chinese Revolution here includes both the period of the armed revolution (192149) and the period of the uninterrupted revolution/ Chinese socialism (1949-77).

5 Friedrich Hegel, drawing a comparison with Western consciousness of the world that created revolutionary history, placed China in the 'childhood' of history. Even Karl Marx, whose theories and insights inspired the Chinese Revolution, described China as a society 'vegetating in the teeth of time', and discovered in the Great Wall of China a metaphor for the universal resistance of non-European societies to change (quoted from Dirlik and Meisner 1989: 17). Max Weber [1904] (1976) also considered Chinese culture (Confucianism) and social patterns (family relations) as structural barriers to the rise of capitalism.

6 'China', in Chinese Zhongguo (the middle kingdom) means that the country lies inbetween the heaven (God) and the earth (globe), which symbolizes the self-perception of being at the centre of the world civilizations.

7 This is part of Mao's understanding of power in which ignorance and illiteracy can be a source of power. In his own words, any beautiful picture can be drawn on a blank sheet of paper.

8 This idiomatic repression means that the implementation of new reform policies should be carried out with great caution, i.e. on a trial basis.

9 The view that China was in 'the primary stage of socialism' was first articulated by the then Party General Secretary Zhao Ziyang at the 13th National Party Congress of the Communist Party of China in 1987. Although he was removed from the Party in the aftermath of the 1989 student unrest, the CCP still adheres to his line of argument of promoting the growth of the productive forces.

10 During the war period, the 'united front' strategy of reducing and simplifying the complexity of politics to an issue of class relations aimed to mobilize political action and raise popular awareness. The question today is whether such complexity could be encompassed in this simplified manner in post-revolutionary society.

11 During the Cultural Revolution, 'red' implied political and class consciousness whereas 'expertise' referred to knowledge, expertise, and technology. It was important that people with technical expertise must first and foremost adopt correct political and class attitude. In other words, 'red' and 'expertise' must be combined, but with the emphasis on the former. 
12 Guanxi in Chinese means 'relations' or 'relationship'. It implies that in dealing with social, business and personal relations, the 'human' or the non-economic aspects of these relations (i.e. friends and family) are placed above economic calculations in importance.

13 For further information on China's private ownership and employment, see Sun Sheng Han and Pannell (1999).

14 During the winter months of 1978-79, some people posted written protests about the problems of China on a blank stretch of wall on Beijing's Changan Avenue calling for political reforms and democracy. This became known as 'Democracy Wall'. One of the key figures behind this movement was Wei Jingshen, a political dissident who now lives in exile abroad.

15 China marked the 110th anniversary of Mao Zedong's birth in December 2003 with a rap song, new books, new memoirs and praise for the communist founder. The Central Committee of CPC also held a seminar at the Great Hall of the People to mark the event with the Party Secretary Hu Jintao delivering a speech praising Mao's historical role and contributions.

\section{REFERENCES}

Alexander, Jeffrey C. 1988. 'The New Theoretical Movement'. In Neil J. Smelser (ed.), Handbook of Sociology. California: Sage Publications.

American Heritage® Dictionary of the English Language 2000. Fourth Edition.

Apter, David E. and Saich, Tony 1994. Revolutionary Discourse in Mao's Republic. Cambridge: Harvard University Press.

Beijing Review 44, 1981.

Chen Feng 1999. 'An Unfinished Battle in China: The Leftist Criticism of the Reform and the Third Thought Emancipation'. The China Quarterly 158.

Chen Zhishang 1984. 'What is the Difference between Bourgeois Humanism and Socialist Humanism?' Red Flag (Beijing), 3 February.

Derrida, Jacques 1973. Speech and Phenomena. Translated by David B. Allison, preface by Newton Garver. Evanston: Northwestern University Press.

-1976. Of Grammatology. Translated by Gayatri Chakravorty Spivak. Baltimore: Johns Hopkins University Press.

-1978. Writing and Difference. Translated by Alan Bass. Chicago: University of Chicago Press.

Dirlik, Arif 1989. 'Revolution Hegemony and the Language of Revolution: Chinese Socialism between Present and Future'. In Arif Dirlik and Maurice Meisner (eds), Marxism and the Chinese Experience. New York: M.E. Sharpe.

-2003. "'The Predicament of Marxist Revolutionary Consciousness": Mao Zedong, Antonio Gramsci, and the Reformulation of Marxist Revolutionary Theory'. Modern China 9 (2): 182-211.

Dirlik, Arif and Meisner, Maurice (eds) 1989. Marxism and the Chinese Experience. New York: M.E. Sharpe.

Eckstein, Alexander 1977. China's Economic Revolution. London: Cambridge University Press.

Gee, James Paul 1999. An Introduction to Discourse Analysis: Theory and Method. London: Routledge.

Gramsci, Antonio 1971. Selections from the Prison Notebooks of Antonio Gramsci. Edited and translated by Quintin Hoare and Geoffrey Nowell Smith. London: Lawrence \& Wishart.

Kapur, Harish (ed.) 1987. As China Sees the World. London: Frances Pinter Publisher.

Kung Chungwu 1975. 'Cultural Revolution in Modern Chinese History'. In Victor Nee and James Peck (eds) China's Uninterrupted Revolution from 1840 to the Present. New York: Random House. 
Li Peilin 1997. 'Changes in the Class and Stratification Structure and Interest Distribution in the New Epoch'. Social Sciences in China, 18 (3).

Li Xing 1998. 'A Gramscian Approach in Conceptualizing the Crisis of Socialism: Some Reflections on the Chinese Socialist Experience'. Development Research Series, Working Paper (62) Aalborg. Research Center on Development and International Relations, Denmark.

- 1999. 'The Transformation of Ideology from Mao to Deng: Impact on China's Social Welfare Outcome'. International Journal of Social Welfare 8 (2): 86-96.

-2001. 'The Chinese Cultural Revolution Revisited'. The China Review 1 (1): 137-65.

Lu Zhichao 1983. 'Assess Socialist Society with the Theory of Development of Dialectical Materialism'. China Report, Red Flag (14).

Meisner, Maurice 1997. 'The Other China'. Current History (September).

Ogden, Suzanne 1996. Book review: 'Socialism Redefined'. The Review of Politics 58 (Summer).

Peck, James 1975. 'Revolution versus Modernization and Revisionism: a Two-Front Struggle'. In Victor Nee and James Peck (eds), China's Uninterrupted Revolution from 1840 to the Present. New York: Random House.

Selden, Mark (ed.) 1979. The People's Republic of China: A Documentary History of Revolutionary Change. New York: Monthly Review Press.

- 1989. 'Mao Zedong and the Political Economy of Chinese Development'. In Arif Dirlik and Maurice Meisner (eds), Marxism and the Chinese Experience. New York: M.E. Sharpe.

Su Shaozhi 1983. Democratization and Reform. Nottingham: Spokesman.

-1990. 'The Role of the Party in the Chinese Post-Mao Reform Process'. Copenhagen Papers 5: 137-46.

Sun Sheng Han and Clifton W. Pannell 1999. 'The Geography of Privatization in China, 1978-1996'. Economic Geography 75 (3): 272-96.

Weber, Max [1904] 1976. The Protestant Ethic and the Spirit of Capitalism. London: Allen \& Unwin.

Weil, Robert 1996. Red Cat, White Cat: China and the Contradictions of 'Market Socialism'. New York: Monthly Review Press.

White, Gordon 1982. 'Why Did China Fail to Follow the Japanese Road?' In Manfred Bienefeld and Martin Godfrey (eds) The Struggle for Development, National Strategies in an International Context. New York: John Wiley \& Sons Limited. 